ISSN 0103-5150

Fisioter. Mov., Curitiba, v. 28, n. 2, p. 349-356, Apr./June 2015

Licenciado sob uma Licença Creative Commons DOI: http://dx.doi.org.10.1590/0103-5150.028.002.A015

\title{
Comparison of static balance of elderly women through two methods: computerized photogrammetry and accelerometer
}

\section{Comparação do equilíbrio estático de idosas avaliadas por meio de dois métodos: fotogrametria computadorizada e acelerômetro}

\section{Dirciane Stieven de Oliveira ${ }^{[a]}$, Gisele Oltramari ${ }^{[a]}$, Rodrigo Costa Schuster ${ }^{[a]}$, Daniel Tiago da Costa de Oliveira ${ }^{[b] *}$}

[a] Faculdade da Serra Gaúcha (FSG), Caxias do Sul, RS, Brazil

[b] Universidade do Vale do Rio dos Sinos (Unisinos), Caxias do Sul, RS, Brazil

\section{Abstract}

Introduction: The aging process produces functional and structural deficits in the body, among these changes we highlight the changes in balance. Objective: This study aims to compare the computed photogrammetry and accelerometer to assess static balance in the elderly. Methods: This was an observational, cross-sectional study. The study included 112 female subjects participating in a mothers club, where the balance assessment was performed using computerized photogrammetry and accelerometer. Results: Average age $70.3 \pm 5.8$ [6079] years, with the majority of the sample (47.3\%) consisted of elderly widows, followed by $41.1 \%$ of married elderly. Most of the sample (73.2\%) reported not working, eighty-six percent of the sample reported not having suffered falls in the last year. The vast majority of elderly studied $(93.8 \%)$ reported not having suffered

* DSO: grad., e-mail:dirciane.fisio@gmail.com GO: MSc, e-mail: gisele.oltramari@fsg.br RCS: MSc, e-mail: rodrigo.schuster@fsg.br DTCO: grad., e-mail: daniel.cosoli@gmail.com 
fracture episode and $6.3 \%$ reported having suffered fracture episode in the last three months, $75 \%$ of the sample owned anteriorization trunk, $63 \%$ had previous oscillation trunk and $37 \%$ had subsequent oscillation. Conclusion: There were significant direct and a moderate to good between the measurements obtained in photogrammetry and triaxial accelerometer correlations.

Keywords: Aging. Balance. Photogrammetry. Accelerometry.

\section{Resumo}

Introdução: $O$ processo de envelhecimento gera deficits funcionais e estruturais no organismo, dentre essas alterações podemos destacar as alterações no equilíbrio. Objetivo: $O$ presente trabalho tem como objetivo comparar a fotogrametria computadorizada e o acelerômetro na avaliação do equilíbrio estático de idosos. Métodos: Trata-se de um estudo tipo observacional e transversal. Participaram do estudo 112 indivíduos do sexo feminino que participam de um clube de mães, onde foi realizada a avaliação do equilíbrio por meio da fotogrametria computadorizada e do acelerômetro. Resultados: Média de idade de 70,3 \pm 5,8 [60-79] anos, a maior parte da amostra (47,3\%) foi constituída por idosas viúvas, seguida de $41,1 \%$ de idosas casadas. Grande parte da amostra (73,2\%) referiu não trabalhar, $86 \%$ da amostra referiu não ter sofrido quedas no último ano. A grande maioria das idosas estudadas (93,8\%) referiu não ter sofrido episódio de fratura e 6,3\% referiu ter sofrido episódio de fratura nos últimos três meses, $75 \%$ da amostra possuiu anteriorização de tronco, 63\% apresentou oscilação anterior do tronco e $37 \%$ apresentou oscilação posterior. Conclusão: Observou-se correlações significativas, diretas e de magnitude moderada entre as medidas obtidas na fotogametria e o acelerômetro triaxial.

Palavras-chave: Envelhecimento. Equilíbrio. Fotogrametria. Acelerometria.

\section{Introduction}

Population aging is well established in developed countries and is constantly on the rise in developing countries, such as Brazil $(1,2)$. According to the Instituto Brasileiro de Geografia e Estatística (3), in Brazil the combined decline in fertility and mortality rates has caused changes in the age structure of the population, with a relative decrease in the younger population and the proportional increase of the elderly. The population over 60 years of age is approximately $11 \%$ of the general population by the year 2020, according to projections, the number of people 100 years old and over will increase 15 -fold, from 145,000 people in 1999 to 2.2 million in 2050 (3).

As life expectancy increases, people start to live with risk factors such as chronic degenerative diseases. These diseases lead to dysfunction of multiple organs on the elderly, such as posture and balance disorders (4). According to Gazzola et al. (5) the aging process affects all postural control components - sensory (visual, somatosensory and vestibular), effector (strength, range of motion, biomechanical alignment, flexibility) and central processing. The integration of the various body systems under central command is critical for the control of body balance. The performance of these systems has a direct in the skills of the individual to perform daily tasks, i.e., the functional capacity. In more than half of the cases, imbalance originates between 65 and 75 years, approximately and about $30 \%$ of elderly patients have the symptoms at this age (6).

To Kisner and Colby (7) balance is the ability to align the segments of the body against gravity to keep or move the body (center of mass) within the available support base without falling. The ability to move the body in balance, under the action of gravity, by the interaction of sensory and motor systems. To assess the balance, numerous methods and scales have been developed with the aim of establishing parameters for identifying elderly with greater susceptibility to suffer falls. Among them we can mention the Functional Reach Test (FRT) (8), the test "Timed Up 
and Go" $(8,9)$, the Physical Performance Test (10), the Berg Balance Scale $(10,11)$; and the March Evaluation and Performance Oriented Balance at (Performance Oriented Mobility Assessment (POMA) (12).

According to Rebelatto et al. (13), falls are treated as a factor of great epidemiological relevance, social and economic in the world because it is the most common type of accident among the elderly. Its complications are the leading cause of deaths in people over 65 and promotes physical, psychological and social, as it leads to dependence and the reduction of daily and trust activities, changing the lifestyle of the elderly (13). Therefore, the importance of body balance, because the earlier the identification of the fastest balance deficit preventive physical therapy measures can be taken, thus avoiding the risk of falls and other complications in this population. Functional assessment of body balance in the elderly is a process that assesses various systems involved in postural control mechanism. Various scales and functional tests have been developed with the purpose of identifying impaired balance and determine the risk factors for independence and falls in the elderly, as mentioned earlier. These scales and tests, have quantitative description of functional balance ability, and can be useful for generating hypotheses about the determinants of functional limitation observed, moreover, this type of evaluation measures in a balancing instrument, the correlation of an observer (reliability intraexaminer).

Among these tools, today we can mention Computed and accelerometry photogrammetry. Computed photogrammetry developed by the application of photogrammetric principles to photographic images obtained in body movements. To these images Photointerpretation bases were applied, generating a new kinematics study tool (14). As for Mello (15) and Watson (16), computerized photogrammetry is a tool used as an aid during physical examination to quantify postural changes and changes in static equilibrium. The accelerometry in health care is a method of kinematic motion analysis, normally used for biomechanical analysis. Allows through the use of accelerometers mensurarem accelerations of the evaluated object. These measurements to generate a sequence of product values representing the instantaneous value of the acceleration as a function of time (17). When this feature is exploited in the human body, one can study the acceleration caused or suffered by the body, with the data derived from the speed, spatial positioning and the inclination with respect to gravity. The accelerometer has as its basic principle the action of acceleration in a mass to produce force (18).

Thus the aim of this study was to compare the assessment of static equilibrium of elderly individuals using two different quantitative tools: computerized photogrammetry and the accelerometer. In addition, we chose to evaluate the cervical position in the sagittal plane to evaluate the cervical posture of the population, taking into account that any cervical change can alter the balance of the elderly.

\section{Methods}

This research was characterized as a study of observational and cross-sectional, which were applied two descriptive quantitative methods for evaluating the static equilibrium of elderly residents in the city of Caxias do Sul. The study was approved by the Ethics Committee on Workers' Circle Research Caxiense/ FSG under number 419 110/2013.

The study comprised subjects female members of the Mothers Club in the city of Caxias do Sul, aged 60 to 79 years, who met the inclusion criteria and who wished to willingly participate in the study and signed the term of Consent.

Inclusion criteria were: female, aged 60 to 79 years, participants of the southern Caxias mothers club, wander so independently without auxiliary aid device, have preserved cognition enough to understand the guidelines, express interest free to participate, sign the Consent Statement. Exclusion criteria were: having neurological or musculoskeletal which cause changes in postural balance, device use auxiliary gear diagnosed with change labyrinth with cognitive change above 79 , with severe visual change under medication effects that might interfere with balance and vestibular function, as hypnotics, sedatives, opioids antipsychotics and antihistamines, joint deformities in the lower limbs that limit walking, individuals who refuse to sign the Instrument of Consent.

To evaluate static balance by means of computerized photogrammetry was used a digital camera (Canon brand with 14.1 megapixel resolution), positioned parallel to the floor, on a level tripod brand (Vivitar), where volunteers were positioned at a distance that could record all the body. Participants remained standing upright all bare where they were 
positioned and aligned. A helmet with an aligned pointer to a plumb line, weighing approximately 60 grams was aligned with the pinna law in order to assess the oscillations in the sagittal plane. All individuals have adopted the standing position and with eyes closed for 30 seconds, where the shooting took place. In order to obtain the moment of greatest oscillation, the images were analyzed by Windows Movie Maker program, and at the moment of greater sway the image was recorded on the computer and analyzed in Software Auto $\mathrm{CAD}^{\mathrm{TM}}$ determining the values of fluctuating degrees. For the analysis of static balance through triaxial accelerometer we developed a software for the operating system Android 4.2 that was installed on a cell of Samsung ${ }^{\mathrm{TM}}$ brand. This software is able to read and interpret real-time data from the mobile device accelerometer and turn it into information relating to change the center of gravity of the individual.

For the assessment of the balance through the accelerometer, individuals used the same helmet that was carried out Photogrammetry Computed where this helmet has a socket for the mobile device. In the same time it was done shooting for the registration of computed photogrammetry were captured oscillations with the accelerometer and the data were stored on a flash drive for further analysis.

\section{Statistical analysis}

The collected data were stored in a Microsoft Office Excel 2007 spreadsheet. Thus, descriptive statistics to characterize the sample were used, which are described as mean and standard deviation. We used the Pearson's correlation coefficient to verify the concurrent validity between the measurements obtained in Biofotogametria and Triaxial Accelerometer. According to Portney and Watkins (19), the correlations were classified as low or no $(0.00<\mathrm{r}<0.25)$, reasonable $(0.25<\mathrm{r}<0.50)$, moderate to good $(0.50$ $<\mathrm{r}<0.75)$ and good to excellent $(\mathrm{r}>0.75)$. All calculations were performed using SPSS for Windows version 17.0 and the significance level was $\alpha<0.05$.

\section{Results}

The evaluated sample consisted of 112 elderly women with a mean age of $70.3 \pm 5.8$ [60-79] years. The vast majority of the sample $(47.3 \%)$ consisted of elderly widows, followed by $41.1 \%$ of married elderly. Twenty-seven percent of the sample reported having completed primary, followed by $21 \%$ of the sample with incomplete primary. Most of the sample $(73.2 \%)$ reported not working; $16.1 \%$ reported doing volunteer work, $9.8 \%$ reported performing paid work and $0.9 \%$ could not answer.

It was found that eighty-six percent of the sample reported having not suffered falls and 14\% reported episode of decrease in the last three months. The vast majority of the studied elderly (93.8\%) reported not having suffered episode of fracture and $6.3 \%$ reported having suffered fracture episode in the last three months. About half of the sample (53.6\%) reported practicing some form of regular physical activity, according to data in Table 1.

Most of the sample (75\%) owned anterior cervical. Sixty-three percent of the sample had anterior trunk oscillation and $37 \%$ had posterior oscillation, described in Table 2.

\section{Concurrent validity}

To establish the relationship between the performance of the accelerometer and the performance of computerized photogrammetry, already having its known validity, we used the correlation test to test the concurrent validation. There were significant correlations, direct and with good magnitude between the measurements obtained in Photogrammetry and Triaxial Accelerometer $(r=0.67 ; p=0.000)$ (Table 3).

Table 1 - Sociodemographic and clinical characteristics of the participants

\begin{tabular}{lr}
\hline Variable & (To be continued) \\
\hline Gender & $(\mathbf{n}=\mathbf{1 1 2})$ \\
Male & $0(0 \%)$ \\
Female & $112(100 \%)$ \\
Age & \\
Between 60 to 69 years & $51(45.54 \%)$ \\
Between 70 to 79 years & $61(54.46 \%)$ \\
Marital Status & \\
Maiden & $4(3.6 \%)$ \\
Married & $46(41.1 \%)$ \\
Widow & $53(47.3 \%)$ \\
Divorced & $6(5.4 \%)$ \\
NA & $2(1.8 \%)$
\end{tabular}


Table 1 - Sociodemographic and clinical characteristics of the participants

(Conclusion)

\begin{tabular}{lr}
\hline Variable & $(\mathbf{n}=112)$ \\
\hline Work activity & \\
None & $82(73.2 \%)$ \\
Volunteer & $18(16.1 \%)$ \\
Paid & $11(9.8 \%)$ \\
NA & $1(0.9 \%)$ \\
Fear of falling & \\
No & $30(26.8 \%)$ \\
Yes, sometimes & $68(60.7 \%)$ \\
Yes, often & $14(12.5 \%)$ \\
Falls & \\
No & $96(85.7 \%)$ \\
Yes, on the last three months & $16(14.3 \%)$ \\
Fractures & \\
No & $105(93.8 \%)$ \\
Yes, on the last three months & $7(6.3 \%)$ \\
Physical Activity & \\
No & $52(46.4 \%)$ \\
Yes & $60(53.6 \%)$ \\
\hline
\end{tabular}

Note: $\mathrm{NA}=$ not applicable.

Table 2 - Range trunk and change in cervical posture measured with computerized photogrammetry

\begin{tabular}{ll}
\hline Variable & $(\mathbf{n}=\mathbf{1 1 2})$ \\
\hline Cervical anteriorization & \\
No & $28(25 \%)$ \\
Yes & $84(75 \%)$ \\
Trunk range & \\
Anterior & $71(63.4 \%)$ \\
Posterior & $41(36.6 \%)$ \\
\hline
\end{tabular}

Table 3 - Average swing degrees measured by computer photogrammetry and accelerometer

\begin{tabular}{lc}
\hline Variable & Degrees \\
\hline Computed photogrammetry & $3.52^{\circ}$ \\
Accelerometer & $3.98^{\circ}$ \\
\hline
\end{tabular}

\section{Discussion}

The increase in life expectancy and the consequent growth of the elderly population in Brazil is increasing concern for the well being and the maintenance and/or the search for a better quality of life in this population. According to Ruwer et al. (6) aging impairs the central nervous system capability to process vestibular, visual and proprioceptive signals responsible for maintaining body balance. These degenerative processes are responsible for significant changes in the geriatric population, including shifting the balance, resulting in falls. According Bittar et al. (20) falls are the most dangerous consequences of imbalance and difficulty in walking, taking the old isolation, decreased activities of daily living (ADL), and low self-esteem.

In the present study found that the average age of the study population was 70.3 years, where the vast majority of the sample (47.3\%) consisted of elderly widows, followed by $41.1 \%$ of married elderly. In an epidemiological study by Pilger et al. (21) with 359 elderly where the goal was to describe the sociodemographic and elderly health conditions in a city of Paraná State, Brazil, stood out the highest percentage of women $(64.4 \%)$, which may be related to greater female longevity compared to men. Other factors were also assigned as the lower exposure to risk factors than men, work-related environment, lower prevalence of smoking and alcohol use, differences in attitude towards disease and disability and the increased coverage of assistance gynecological $(21,22)$. In relation to marital status of the research there was a predominance of widows (43.7\%), corroborating with our results, which can be explained by the fact that these women as widows, mostly end up living alone, and the tendency of widowed men is find another mate (23).

In addition, other data observed with the present study was related to physical activity, where $53.6 \%$ of the women practiced some physical activity. In a study by Freitas (24) with the aim of investigating the impact of physical activity on stabilographic parameters, static and dynamic balance of physically independent elderly, composed of 77 elderly between 60 and 75 years, indicated a significant impact of the practice physical activity on postural control of older, showing that sedentary showed greater postural 
instability compared to their active counterparts physically. Also in the study by Freitas (24) elderly with lower levels of physical activity had greater fluctuations in stabilometric variables, especially in the amplitude of postural sway and speed.

This study also shows that $75 \%$ of older have cervical anterior. Postural changes due to aging begin to manifest from 40 years of age, where the height starts to decrease around an inch per decade (25). Besides the height, other changes resulting from advancing age also begin to manifest mainly in the sagittal plane, for example, increased kyphotic curvature of the thoracic spine, increase or decrease lumbar lordosis, increased knee flexion angle displacement the hip joint back and the trunk bending forward, above the hips, thus changing the body balance (26). With these changes the center of gravity is anterior, and therefore, the elderly end up having a bigger previous oscillation in relation to other changes (13).

In a study by Nunes et al. (27) with 135 individuals separated by age groups, with the lowest 20 years and the largest 60, aimed to evaluate and compare the anteroposterior inclinations and the gravity center of the side, through a postural assessment software. The evaluations indicated a tendency for the anterior and lateralization of the center of gravity according to age group, that is, the older, the greater the risk of anterior trunk in the static posture. According Nashner (28), degree of posterior and lateral oscillation occurs while the balance is being maintained, and these oscillations define the limits of stability in the anterior direction, posterior and lateral, where the normal anteroposterior oscillations in adults is twelve degrees from the rearmost position prior to that over.

Have Gatev et al. (29), states that during the maintenance of upright posture, the angular displacement of the ankle, knee and hip do not exceed four degrees. Thus the reduction in range of motion in these joints would not be a determining factor for postural control in the elderly.

Another finding in this study was related to the average of degrees of postural sway, measured by computed photogrammetry, with the value of $3.52^{\circ}$. A study by Baraúna et al. (30), in order to verify through computerized photogrammetry static balance amputees, comparing them to non-amputee subjects, proved to be easy to apply in the evaluation of static balance, making it clear that it is a tool to assess the balance quantitatively. Baraúna et al.
(30) believe that the evaluation of static equilibrium as a tool using computerized photogrammetry can be a support for the development of preventive and therapeutic approaches, thus avoiding complications due to imbalance.

In a study by Carneiro et al. (31), aimed to verify the inter-rater reliability and Intra-examiner of computed photogrammetry for postural assessment of head in side view in 25 individuals. Performed by two examiners, resulted in excellent correlation between Intra-examiner analysis, but for inter showed low reliability, being justified by the limited experience of the examiner with the method due to difficulties in the implementation of photogrammetry, and for data analysis. As the average for the degrees of oscillation displayed on accelerometer, with values of $3.98^{\circ}$. According Mathie et al. (32), the motion sensors are accelerometers are sensitive to variations in body acceleration in one or three axes of the body, so they are able to directly and objectively quantify the frequency, intensity and duration of the motion. In a systematic review by Azevedo et al. (33), on the methodological characteristics of studies in Latin America using motion sensors, eighty percent of the studies used accelerometers.

In a study by 0'Sullivan et al. (34) aimed to determine the correlation between accelerometry and clinical patterns (Berg Balance Scale and the TUG test), to characterize accelerometer responses and acceleration patterns between fallers and non-fallers, the authors report that the Berg Balance Scale, tends to be subjective, while the TUG quantifies a functional impairment of the individual, but it requires a subjective evaluation to balance the assessment. Other alternatives require sophisticated and expensive equipment, therefore, the accelerometer is a potential solution to the problem, reaching the conclusion that it was the first type study which showed a high correlation between the instruments and accelerometry can also distinguish between stabilizing responses to different equilibrium conditions, proving to be an efficient alternative, quantitatively measuring the balance of the elderly.

In a study by Weiss et al (35) where the objective was to verify if the accelerometer could increase the usefulness of the TUG in the evaluation of patients with Parkinson's disease, the result proved to be satisfactory, taking a sensible approach able to identify and document the progression of the disease and to evaluate the response and benefits for different 
therapeutic interventions. In the study by Dalton et al. (36) in order to investigate the ability of a single triaxial sensor detecting a motion deficiency in individuals with pre-manifest and manifest Huntington's disease (HD), the sensor showed excellent agreement. And therefore the main objective of the study, the evaluation of static balance in the elderly by the methods of computerized photogrammetry and accelerometry, it was observed that the accelerometer can be effective to measure postural sway elderly, thus minimizing the possible errors in the implementation and analysis of computerized photogrammetry.

\section{Conclusion}

The accelerometer shown in this study, to be an effective evaluation tool for the static equilibrium of the elderly. Importantly also, which is a user-friendly tool, requires little time, besides being handy and portable allowing the evaluation of volunteers in different locations. Through this instrument, the physical therapist can monitor and better monitor his patient to develop a treatment plan. It is suggested yet to be realized more studies comparing the accelerometer and Computed photogrammetry in order to prove their reliability, since there are no studies in the literature comparing the two assessment tools.

\section{References}

1. Carvalho JAM, Garcia RA. 0 envelhecimento da população brasileira: um enfoque demográfico. Cad Saúde Pública. 2003;19(3):725-33.

2. Garrido R, Menezes PR. O Brasil está envelhecendo: boas e más notícias por uma perspectiva epidemiológica. Rev Bras Psiquiatr. 2002;24(Supl. 1):3-6.

3. Instituto Brasileiro de Geografia e Estatística. Perfil dos idosos responsáveis por domicílios no Brasil. 2002 [cited 2013, Apr 26]. Available from: www.ibge. gov.br/home/presidencia/noticias/25072002pidoso. sht

4. Maciel ACC, Guerra RO. Prevalência e fatores associados ao déficit de equilíbrio em idosos. R Bras Ci e Mov. 2005;13(1):37-44.
5. Gazzola JM, Perracini MR, Ganança MM, Ganança FF. Fatores associados ao equilíbrio funcional em idosos com disfunção vestibular crônica. Rev Bras Otorrinolaringol. 2006;72(5):683-90.

6. Ruwer SL, Rossi AG, Simon LF. Equilíbrio em idosos. Rev Bras Otorrinolaringol. 2005;71(3):298-303.

7. Kisner C, Colby LA. Exercícios terapêuticos: fundamentos e técnicas. 4. ed. Barueri: Manole; 2005.

8. Duncan PW, Weiner DK, Chandler J, Studenski S. Functional reach: a new clinical measure of balance. J Gerontol. 1990;45(6):M192-7.

9. Podsiadlo D, Richardson S. The timed "Up \& Go": a test of basic functional mobility for frail elderly persons. J Am Geriatr Soc. 1991;39(2):142-8.

10. Smith PS, Hembree JA, Thompson ME. Berg Balance Scale and Functional Reach: determining the best clinical tool for individuals post acute stroke. Clin Rehabil. 2004;18(7):811-8.

11. Berg KO, Wood-Dauphinee SL, Williams JI, Gayton D. Measuring balance in the elderly: preliminary development of an instrument. Physiother Can. 1989;41(6):304-11.

12. Tinetti ME, Baker DI, Garret PG, Gottschalk CM, Koch ML, Horwitz RI. Yale FICSIT: risk factor abatement strategy for fall prevention. J Am Geriatr Soc. 1993;41(3):315-20.

13. Rebelatto JR, Castro AL, Sako FK, Aurichio TR. Equilíbrio estático e dinâmico e o índice de massa corporal. Fisioter Mov. 2008;21(3):69-75.

14. Ricieri DV. Validação de um protocolo de fotogrametria computadorizada e quantificação angular do movimento tóraco-abdominal durante a ventilação tranqüila [dissertação]. Uberlândia: Centro Universitário do Triângulo; 2000.

15. Mello MSI, Maia JN, Silva DAL, Carvalho CC. Avaliação postural em pacientes submetidas à mastectomia radical modificada por meio da fotogrametria computadorizada. Rev Bras Cancerol. 2011;57(1):39-48.

16. Watson AWS. Procedure for the production of high quality photographs suitable for the recording and evaluation of posture. Rev Fisioter Univ São Paulo. 1998;5(1):20-6. 
17. Robertson G, Caldwell G, Hamill J, Kamen G. Whittlesey S. Research methods in biomechanics. Champaign: Human Kinetics; 2004.

18. Balbinot A, Brussamarello VJ. Instrumentação e fundamentos de medidas. Rio de Janeiro: LT C; 2007. v. 2.

19. Portney LG, Watkins MP. Foundations of clinical research: appications to practice. 3rd ed. New Jersey: Prentice Hall Health; 2009.

20. Bittar RSM, Pedalini MEB, Bottino MA, Formigoni LC. Síndrome do desequilíbrio no idoso. Pró-fono. 2002;14(1):119-28.

21. Pilger C, Menon MH, Mathias TAF. Características sociodemográficas e de saúde de idosos: contribuições para os serviços de saúde. Rev Latino-Am. Enfermagem. 2011;19(5):1230-8.

22. Silva RC, Malina RM. Nível de atividade física em adolescentes do município de Niterói, Rio de Janeiro, Brasil. Cad Saúde Pública. 2006;16 (4):1091-7.

23. Baldin CB, Fortes VLF. Viuvez feminina: a fala de um grupo de idosas. Rev Bras de Ciên do Envelh Hum. 2008;5(1):43-54.

24. Freitas ERFS. Prática habitual de atividade física afeta o equilíbrio de idosas? Fisioter Mov. 2013;26(4):813-21.

25. Shephard R. Envelhecimento, atividade física e saúde. São Paulo: Phort; 2003.

26. Kendall FP, McCreary EK, Romani WA, Rodgers MM, Provance PG. Músculos: provas e funções com postura e dor. Trad. Lilia Breternitz Ribeiro. 4. ed. Barueri: Manole;1995.

27. Nunes ADM, Fonseca LCS, Scheicher ME. Comparação das inclinações lateral e anteroposterior no equilíbrio estático entre jovens, adultos e idosos. Rev Bras Geriatr Gerontol. 2013;16(4):813-20.

28. Nashner LM. Sensory, neuromuscular, and biomechanical contributions to human balance. In: Proceedings of the American Physical Therapy Association Forum; 1989 Jun 13-15;Nashville, TN, USA.
29. Gatev P, Thomas S, Kepple T, Hallett M. Feedforward ankle strategy of balance during quiet stance in adults. J. Physiol. 1999;514(Pt 3):915-28.

30. Baraúna MA, Duarte F, Sanchez HM, Canto RST, Malusa S, Campelo-Silva CD, et al. Avaliação do equilíbrio estático em indivíduos amputados de membros inferiores através da biofotogrametria computadorizada. Rev Bras Fisioter. 2006;10(1):83-90.

31. Carneiro PRC, Cardoso BS, Cunha CM, Teles LCS. Confiabilidade inter e intraexaminador da avaliação postural da cabeça por fotogrametria computadorizada. Fisioter Pesqui. 2014;21(1):34-9.

32. Mathie MJ, Coster ACF, Lovell NH, Celler BG. Accelerometry: providing an integrated, practical method for long-term, ambulatory monitoring of human movement. Physiol Meas. 2004;25(2):R1-20.

33. Azevedo AMP, Ferreira ACD, Silva PPC. Características metodológicas de estudos realizados na América Latina usando sensores de movimento: revisão sistemática. R Bras Ci e Mov. 2010;18(1):89-99.

34. O’Sullivan M, Blake C, Cunningham C, Boyle G, Finucane $C$. Correlation of accelerometry with clinical balance tests in older fallers and non-fallers. Age Ageing. 2009;38(3):308-13.

35. Weiss A, Herman T, Plotnik M, Brozgol M, Maidan I, Giladi N, et al. Can an accelerometer enhance the utility of the Timed Up \& Go Test when evaluating patients with Parkinson's disease? Med Eng Phys. 2010;32(2):119-25.

36. Dalton A, Khalil H, Busse M, Rosser A, van Deursen R, Ólaighin G. Analysis of gait and balance through a single triaxial accelerometer in presymptomatic and symptomatic Huntington's disease. Gait Posture. 2013;37(1):49-54.
Received: 07/15/2014 Recebido: 15/07/2014

Approved: 02/27/2015 Aprovado: 27/02/2015 